\title{
Strategic Planning And Its Relationship With Business Performance Among Small And Medium Enterprises In South Africa
}

Maxwell Sandada, Vaal University of Technology, South Africa David Pooe, Vaal University of Technology, South Africa Manilall Dhurup, Vaal University of Technology, South Africa

\begin{abstract}
Strategic planning is a business tool that small and medium businesses need in today's dynamic and highly competitive business environment. It has a potential to cushion these enterprises from such unpredictable harsh business conditions. The purpose of this paper was to establish the relationship between strategic planning practices and business performance among SMEs in the Gauteng province of South Africa. Data were analysed from 200 useable questionnaires that were distributed to SME owners/managers. Factor analysis, correlations, and regression techniques were used in order to extract the dimensions of strategic planning and their relationships with business performance. Environmental scanning, business mission and vision, formality of strategic plans, evaluation and control, informing sourcing, strategy implementation incentives, employee participation, and time horizons emerged as strategic planning dimensions. The results confirm that strategic planning has a positive association and predictive relationship with the performance of SMEs. The results of this study can serve as a guide to SME owners and managers to properly implement strategic planning practices which will enable them to propel and sustain their businesses in turbulent and uncertain business environments.
\end{abstract}

Keywords: SMEs; Strategic Planning; Business Performance; Gauteng; South Africa

\section{INTRODUCTION}

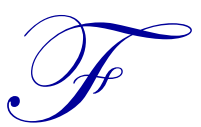

aced with increasing competition and dynamic market conditions, many SMEs in South Africa and in other countries are increasing their efforts to understand how they can improve their performance. To be competitive, some strategic management scholars and policymakers have advocated for more strategic planning practices. However, there is an unresolved debate amongst researchers about the effect of strategic planning on business performance. Whilst studies were conducted to establish the relationship between strategic planning and business performance, the evidence has been mixed (Andersen, 2000; Falshaw, Glaister, \& Tatoglu, 2006). Consequently, conflicting views about the effect of strategic planning on business performance still exists.

Advocates of non-formalised strategic planning argue that it has no performance benefit to SME business. Their argument is that strategic planning has a tendency to cause rigidity in a business organisation which minimises its ability to be adaptive to the dynamic and competitive environment (Mintzberg, 1994; Saffu \& Manu, 2003). Conversely, advocates of formalised strategic planning indicate that several performance benefits are attributed to strategic planning (Desai, 2000; Kraus, Harms, \& Schwarz, 2006). They posit that strategic planning is a management tool which cushions businesses from unstable and competitive markets. Further, Schraeder (2002) posits that strategic planning provides an operational framework which allows an organisation to enjoy competitive advantages and improved performance.

\section{LITERATURE REVIEW}

The review of literature provides a discussion about strategic planning and business performance measures. 


\section{Strategic Planning}

Odame (2007, p. 10) defines strategic planning as a "method of formulating and implementing long-term plans in a broad and flexible manner in order to achieve the aspirations of the organisation." The main components of strategic planning practices entail asking questions on where the business wants to be, the present position of the business, means to get where it wants to be, and what changes will take place in the business's environment (Huang, 2006) According to Dincer, Tatoglu, and Glaister (2006), the key aspects of strategic planning include the formulation of a mission statement of the enterprise, establishing the objectives, crafting and implementing the strategies, and monitoring and controlling the progress in strategy implementation. In other words, the enterprise plans for the future by envisioning how and what the future will be like and then making decisions based on those perceptions of the future. O'Regan and Ghobadian (2004) have observed that key aspects of strategic planning include the long term view of an organisation, defining the line of business and ensuring a strategic 'fit' or 'balance' between the business and its environment. This notion suggests that a strategic fit helps an organisation to capitalise on opportunities that arise and to minimise the threats posed by unstable market environments.

Desai (2000) asserts that businesses should undertake strategic planning because their environments are becoming increasingly complex and unstable. This shows that strategic planning practices would therefore help SMEs mangers/owners to know where they are, where they are going and how to manage uncertainties in the business environment. Desai (2000) further opines that strategic planning creates a viable link between a business' mission, vision, goals, objectives, strategic choices, and resources. A number of studies have been undertaken on the benefits of strategic planning (Desai, 2000; Fraser \& Stupak, 2002; Goncalves, 2009). The studies reveal that strategic planning enables businesses to identify causes and solutions to problems, to understand the operating environment, to define the purpose of the business, and to clarify the ambitions, values, and resources of a business. The more a business practices strategic planning, the more it is able to create stability in spite of a dynamic environment. According to Fraser and Stupak (2002, p. 1205), strategic planning may "encourage the clarification of business goals, systematic gathering of information, prioritisation of projects, teamwork, environmental responsiveness, communication of strategic intent to all stakeholders, and an improved performance." The authors are of the view that the strategic planning process may strategically position a business by striking a balance between how it operates and the requirements of the environment. From the foregoing arguments, proponents of the strategic planning process sustain the view that strategic planning may not be regarded as panacea to business success, but if well managed, businesses are able to clarify future direction, establish priorities, effectively respond to the dynamic business environment and, hence, improve their performance.

\section{Business Performance}

How to measure business performance still remains a contentious subject to business practitioners and academic communities alike (Tang \& Zhang, 2005; Punn \& White, 2005). However, several researchers tend to agree that organizations can generally use the objective rather than subject measures to assess their success, provided that accurate information is provided (Chow \& Van der Stede, 2006; Panigyrakis \& Theodoridis, 2009). While objective measures include financial records; namely, actual profit, turnover, return on investment, return on capital employed, and inventory turnover, subjective measures tend to rely on managers' and key role players' (owner) perceptions of business performance (Phillips, Davies, \& Moutinho, 1999).

Critics of objective measures of business performance report that objective measures are inaccessible, confidential, incomplete, and often inaccurate (Chong, 2008). Profit figures are subjected to manipulations, which make comparisons among different sectors difficult. In a similar vein, Chow and Van der Stede (2006), and Atkinson and Brown (2001) argue that objective measures are unreliable because they are too aggregated and backward looking rather than forward looking, stressing the short-term future of the organization instead of the longterm benefits. Managers (owners) are therefore unable to understand the root causes of performance problems and make cross-functional decisions in order to survive in turbulent business environments. A study by Tang and Zhang (2005) reveals that objective performance data are influenced by industry specific factors and hence, are inappropriate for cross-industry comparison.

As a consequence of such inaccuracies, Tang and Zhang (2005) opine that researchers rely on subjective measures because of the difficulty in obtaining objective performance data. With regard to subjective measures, 
performance information is provided in non-monetary terms; for example, market share, customer satisfaction, employee turnover, and new product development, which are relevant to survive in competitive environments (Verbeen \& Boons, 2009). Dawes (1999) argues that with subjective measures, managers (owners) are willing to provide their perceptions about business performance, even if the information required is of a sensitive or confidential nature as they need to survive in a rapidly changing competitive environment. Jusoh and Parnell (2008) further provide affirmations to such arguments that the strength of non-financial measures lies in their ability to provide insight into business processes and outcomes which, in the long term, are better predictors of future business performance.

\section{PROBLEM INVESTIGATED, RESEARCH HYPOTHESES, AND OBJECTIVES}

Despite the benefits of strategic planning to businesses, there is little evidence of empirical research that has sought to evaluate strategic planning within the domain of small business research (French, Kelly, \& Harrison, 2004). Furthermore, Sum, Jukow, and Chen (2004) also concur that despite the widespread recognition of the importance and significant contributions of SMEs, research on these small businesses remains scarce. Phillips (2000) advocated the need for more systematic research aimed at revealing the true nature of strategic planning in SMEs and its relationships.

A review of literature on strategic planning, in general, in South Africa shows that there is a paucity of studies that has focussed on the impact of strategic planning practices of SMEs on business performance. Whilst there were studies conducted in South Africa, they did not specifically hone in on the relationship between strategic planning and business performance among SMEs. Odame (2007), for example, examined strategic planning process in general. Murimbika (2011) examined the relationship between strategic planning and entrepreneurial orientation in the financial and business sectors. Naidoo's (2006) study examined the strategic processes in the retail sector, Laljit (2006) evaluated the business strategy development among SMEs, while studies by Nkulu (2012) and Mohutsiwa (2012) focused on strategic planning small- and medium-sized retailers and the relationship between entrepreneurship and performance of SMEs in South Africa, respectively. Therefore, little is known about strategic planning and its effect on the performance of SMEs in Gauteng province.

Such research, while noteworthy, provides important avenues because they provide invaluable insights for SMEs owners/managers initiatives about how strategic planning activities can provide an enabling mechanism to improve business performance.

Given the dearth of previous empirical work on this subject, this study seeks to evaluate the relationship between strategic planning and the performance of SMEs in the Gauteng province of South Africa. In order to support the objectives of the study, the following hypotheses were formulated.

$\mathbf{H}_{1}: \quad$ Strategic planning exhibits a positive relationship with SME business performance.

$\mathbf{H}_{2}$ : $\quad$ Strategic planning exhibits a significant predictive relationship with SME performance measured by perceptual (subjective) business performance measures.

\section{RESEARCH DESIGN}

The study was located with a positivist, quantitative research paradigm. A positivist research perspective seeks to test and confirm hypothesis in order to explain and predict the effect of one factor on another (Johnson \& Onwuegbuzie, 2004; Schiffman \& Kanuk, 2009; Sedmak \& Longhurst, 2010). This approach was adopted in order to establish the relationship between strategic planning and the performance of SMEs. The population of this study included SMEs operating in Gauteng province. A sample size of 200 SMEs was used in this study. The unit of analysis in this study included SME owners and managers. They were identified based on their job title and position in the business that was responsible for strategic planning.

A structured questionnaire was used. A demographic section solicited information about the ownermanagers - age, sex, marital status, position occupied in the business, respondent's title - as well as the business' characteristics - number of years in business and number of employees. The remaining sections solicited information related to the strategic planning practices and business performance. 
The subject measures of business performance were used in this study because they are perceived as more informative than the objective ones (Falshaw et al., 2006; Tapinos, Dyson, \& Meadows, 2005; Chow \& Van der Stede, 2006; Chong, 2008). Furthermore, concerted efforts to obtain actual performance data were difficult to obtain in the study from mangers/owners of SMEs. Data was collected through personal visits to the identified respondents by the principle researcher. Respondents were given enough time to complete the questionnaires.

The demographic data were analysed using descriptive statistics and factor analysis was utilised to identify the strategic planning practices and the types of business performance. Correlation coefficient analysis was conducted to ascertain the relationships between strategic planning and business performance, and multiple regression analysis was finally used to analyse the predictive relationship between strategic planning factors and business performance.

\section{RESULTS AND DISCUSSION}

\section{Demographic Composition of the Sample}

The demographic distribution of respondents reveals that out of 200 , the majority (121 or $60.5 \%$ ) were male and $79(39.5 \%)$ were female. The majority of respondents $n=59(29.5 \%)$ were in the age category of 26-35 years, followed by 36-45 and 46-55, which accounted for $\mathrm{n}=57(28.5 \%)$ and $\mathrm{n}=51(25.5 \%)$ of the sample, respectively. In addition, 20 respondents (10\%) indicated that they were in the age category of 56 years and older and 13 respondents $(6.5 \%)$ were in the $20-25$ year old category. The majority $(n=107 ; 53.5 \%)$ of the SMEs employ between one and 49 employees, whereas 93 (46.5\%) indicated that they employ between 50 and 200 employees.

In terms the number of years SMEs were in operation, 63 SMEs (31.5\%) were in business for more than 21 years, followed by those which were in operation between 11 and 20 years $(n=48 ; 24 \%)$ and those which were in operation between six and 10 years $(n=45 ; 22.5 \%)$. Finally, those SMEs that were in operations for five years and less $(n=44 ; 22 \%)$ comprise a small part of the sample.

\section{Factor Analysis}

Correlations, measure of sampling adequacy (MSA), and the Bartlett's test of sphercity were used to ensure that the factor analysis is appropriate for the data set. The criteria for the number of factors to be extracted was based on eigenvalue, percentage of variance, significance of factor loading, and an assessment of the factor structure (Kivela, Reece, \& Inbakaran, 1999). Only factors with eigenvalue equal or greater than one were considered significant. A variable was considered of significance and included in a factor when its factor loading was equal to or greater than 0.40 (Hair, Anderson, Tatham, \& Black, 1998). The scale was purified by removing items with low factor loadings, communalities, and low-item-to-total correlations. The iterative process was repeated several times to have a clear factor structure. This process resulted in the extraction of eight strategic planning practices and two business performance dimensions which accounted for $67.85 \%$ and $50.17 \%$ of the cumulative explained variance, respectively, for the two constructs.

Table 1 provides an outline of the strategic planning and business performance sub-dimensions and a brief description of each dimension.

Table 1: Strategic Planning and Business Performance Dimensions

\begin{tabular}{|l|l|}
\hline \multicolumn{1}{|c|}{ Strategic Planning } & \multicolumn{1}{c|}{ Description } \\
\hline Environsions & $\begin{array}{l}\text { Entails the assessing of the business environment in order to gather information about the } \\
\text { variables that affect the business }\end{array}$ \\
\hline Business mission and vision & $\begin{array}{l}\text { Relates to the reason for the existence of the business, its present position and what the future } \\
\text { holds for the business }\end{array}$ \\
\hline $\begin{array}{l}\text { Formality of strategic } \\
\text { planning }\end{array}$ & The extent to which formal methods are used to present the strategic plan \\
\hline Evaluation and control & $\begin{array}{l}\text { Refers to the reviewing of the progress made in achieving the set objectives and targets and } \\
\text { taking corrective action to fix problems that hinder progress }\end{array}$ \\
\hline
\end{tabular}


Table 1 cont.

\begin{tabular}{|l|l|}
\hline Sources of information & Describes where the business gets information about changes in the environment \\
\hline $\begin{array}{l}\text { Strategy implementation } \\
\text { incentives }\end{array}$ & $\begin{array}{l}\text { The monetary and non-monetary rewards that are used by the business to motivate employees } \\
\text { to work hard in order to ensure successful strategy implementation. }\end{array}$ \\
\hline Employee participation & $\begin{array}{l}\text { The involvement of employees in establishing business mission, vision, objectives, and } \\
\text { strategies }\end{array}$ \\
\hline $\begin{array}{l}\text { Time horizon of strategic } \\
\text { planning }\end{array}$ & Relates to the length of the time the business plans ahead \\
\hline Business Performance Dimensions \\
\hline $\begin{array}{l}\text { Internal Business } \\
\text { performance }\end{array}$ & Describes the performance indicators within the business organisation \\
\hline $\begin{array}{l}\text { External business } \\
\text { performance }\end{array}$ & Indicates the performance indicators outside the business organisation \\
\hline
\end{tabular}

\section{Correlation Analysis}

Before conducting a regression analysis, Spearman rho correlation coefficient was computed in order to ascertain the bivariate relationship of the eight factors of strategic planning and business performance. The Spearman's correlation is a non-parametric rank-based statistical test for unevenly distributed data (Zikmund, Babin, Car, \& Griffin, 2009). The Spearman's correlation was therefore used because the data were ranked and not normally distributed. The correlations range from -1.0 for a perfect negative relationship to +1.0 for a perfect positive relationship (Welman, Kruger, \& Mitchell, 2005). The level of association between strategic planning factors and business performance is summarised in Table 2.

Table 2: Correlations and Reliabilities-Strategic Planning with Business Performance

\begin{tabular}{|l|c|c|c|c|c|c|c|c|c|}
\hline & ES & MV & FS & EC & SI & S11 & EP & TH & EBP \\
\hline Environmental scanning (ES) & 1 & $.473^{* *}$ & $.654^{* *}$ & $.599^{* *}$ & 0.461 & $.354^{* *}$ & $.457^{* *}$ & $.400^{* *}$ & $.548^{* *}$ \\
\hline Mission and vision (MV) & $.473^{* *}$ & 1 & $.510^{* *}$ & $.330^{* *}$ & $.234^{* *}$ & $0.173^{*}$ & $.297^{* *}$ & $.256^{* *}$ & $.424^{* *}$ \\
\hline $\begin{array}{l}\text { Formality of strategic planning } \\
\text { (FS) }\end{array}$ & $.654^{* *}$ & $.510^{* *}$ & 1 & $.513^{* *}$ & $.314^{* *}$ & $.307^{* *}$ & 0.41 & $.341^{* *}$ & $.579^{* *}$ \\
\hline Evaluation and control (EC) & $.599^{* *}$ & $.330^{* *}$ & $.513^{* *}$ & 1 & $.407^{* *}$ & $.427^{* *}$ & $.333^{* *}$ & 0.323 & $.524^{* *}$ \\
\hline Sources of information (SI) & $.461^{* *}$ & $.234^{* *}$ & $.314^{* *}$ & $.407^{* *}$ & 1 & $.290^{* *}$ & $.309^{* *}$ & $.168^{* *}$ & $.384^{* *}$ \\
\hline $\begin{array}{l}\text { Strategy implementation incentives } \\
\text { (SII) }\end{array}$ & $.354^{* *}$ & $.173^{*}$ & $.307^{* *}$ & $.427^{* *}$ & $.290^{* *}$ & 1 & $.119^{* *}$ & $.252^{* *}$ & $.446^{* *}$ \\
\hline Employee participation (EP) & $.457^{* *}$ & $.297^{* *}$ & $.410^{* *}$ & $.333^{* *}$ & $.309^{* *}$ & $.119^{* *}$ & 1 & $.214^{* *}$ & $.366^{* *}$ \\
\hline Time horizon (TH) & $.400^{* *}$ & $.256^{* *}$ & $.341^{* *}$ & $.323^{* *}$ & $.168^{* *}$ & $.252^{* *}$ & $.214^{* *}$ & 1 & $.307^{* *}$ \\
\hline Business performance (BP) & $.548^{* *}$ & $.424^{* *}$ & $.579^{* *}$ & $.524^{* *}$ & $.384^{* *}$ & $.446^{* *}$ & $.366^{* *}$ & $.307^{* *}$ & 1 \\
\hline Cronbach alpha reliability & 0.91 & 0.86 & 0.84 & 0.71 & 0.64 & 0.69 & 0.73 & 0.71 & 0.89 \\
\hline
\end{tabular}

** Correlation is significant at the 0.01 level (2-tailed).* Correlation is significant at the 0.05 level (2-tailed).

The results presented in Table 2 show that the correlations between business performance and the eight factors of strategic planning factors - environmental scanning $(r=.55)$, business mission and vision $(r=.42)$, formality of strategic planning $(r=.58)$, evaluation and control $(r=.52)$, sources of information about the environment $(r=.38)$, strategy implementation incentives $(r=.45)$, employee participation $(r=.37)$, and the time horizon of strategic planning $(r=.31)$ - are positive and significant. Similar findings about the positive correlation between strategic planning and business performance are reported by other scholars such as Mcllquham-Schmidt (2010). The study presents findings that suggest that strategic planning is positively related to business performance. Efendioglu and Karabulut's (2010, p. 3) study also highlights the positive correlation between strategic planning activities and business performance.

\section{The Hypothesis}

$\mathbf{H}_{1}$ : There is a positive relationship between strategic planning and SME business performance. 


\section{Regression Analysis}

Having established the strength of correlations between the variables, the study proceeded to conduct a regression analysis as correlations analysis only measure the strength of a relationship but fail to determine predictive relationship between variables. Regression analysis was performed to test the predictive relationship between two sets of constructs; namely, strategic planning factors and business performance measures. The eight strategic planning factors were used as independent variables and subjective business performance was used as a dependent variable. Table 3 presents the regression results showing the predictive power of each factor on business performance.

Table 3: Regression Analysis between Strategic Planning Factors and Business Performance Measures

\begin{tabular}{|c|c|c|c|c|}
\hline \multicolumn{5}{|l|}{ Dependent Variable: Business Performance } \\
\hline Independent Variables & Std. Error & Beta & t-value & p-value \\
\hline Factor 1 (Environmental scanning) & .055 & .090 & 1.105 & .271 \\
\hline Factor 2 (Business mission and vision & .045 & .082 & 1.327 & .186 \\
\hline Factor 3 (Formality of strategic planning) & .060 & .270 & 3.645 & $.000 *$ \\
\hline Factor 4 (Evaluation and control) & .056 & .149 & 2.140 & $.034 *$ \\
\hline Factor 5 (Source of information) & .044 & .092 & 1.522 & .130 \\
\hline Factor 6 (Strategy implementation incentives) & .036 & .221 & 3.756 & $.000 *$ \\
\hline Factor 7 (Employee participation) & .037 & .070 & 1.168 & .244 \\
\hline Factor 8 (Time horizon of strategic planning) & .035 & .028 & .492 & .623 \\
\hline
\end{tabular}

$\mathrm{R}=.70 ; \mathrm{R}^{2}=.49 ;$ Adjusted $\mathrm{R}^{2}=.47 ; \mathrm{F}=22.88 ; *$ significant at $\mathrm{p}<0.05$

The regression results depicted in Table 3 show that the eight strategic factors had an adjusted $\mathrm{R}^{2}$ value of 0.47 which implies that the strategic planning factors explained approximately $47 \%$ percent of the variance in business performance of SMEs. The beta coefficients reveal that formality of strategic planning makes significant contributions to the business performance of SMEs $(\beta=0.27, \mathrm{p}<.05)$, followed by strategy implementation incentives $(\beta=0.22, p<.05)$ and evaluation and control $(\beta=0.14, p<0.05)$. However, source of information about the environment $(\beta=0.09, \mathrm{p}>0.05)$, business mission and vision $(\beta=0.08, \mathrm{p}>0.05)$, employee participation $(\beta=$ $0.08, p>0.05)$, environmental scanning $(\beta=0.09, p>0.05$ and time horizon of strategic planning $(\beta=0.02, p>$ 0.05 ) showed insignificant contributions to business performance. While these five factors (source of information, environmental scanning, business mission and vision, employee participation, and time horizon of strategic planning) showed an insignificant relationship with business performance, they did not show a negative relationship with business performance, but instead made very small contribution toward business performance. A study by Karami (2008) found that in today's high levels of competition and uncertainty, businesses scan the environment to improve their competitiveness. Popoola's (2000) study of corporate banks in Nigeria revealed that environmental scanning enables banks to gain competitive advantage. With regard to business mission and vision, Forbes and Seena (2006), Mazzarol, Rebound, and Soutar (2009), and Kantabutra (2008) confirm that a business mission and vision statement enhances business performance as it guides in decision-making, and motivates and inspires personnel. Concerning employee participation in strategic planning, Gadiesh and Gilbert (2001) and Speculand (2009) assert that employee participation in strategic planning leads to employee motivation and ensures unity of purpose and cooperation in the business. However, a study by Dincer et al. (2006) on strategic planning of Turkish firms confirms the importance of time horizon of strategic planning in contributing to business performance. Kraus et al. (2006) affirms that formalised strategic plans help a business to achieve goals and to grow. With regard to strategy implementation incentives, Ehlers and Lazenby (2006) posit that incentivising employees is a necessary condition for the success of strategy implementation. Okumus (2003) also asserts that incentives are essential to successful strategy implementation as this leads to business success.

The importance of factors - formality of strategic planning, strategy implementation incentives, and evaluation, and control as predictors of business performance - are also supported by theory. A study of small business formal and non-formal planners by Kraus et al. (2006) revealed that formal planners were able to grow twice as much as non-planners. Strategy implementation incentives are crucial to business performance because they motivate employees in strategy implementation (Ehlers \& Lazenby, 2006). 


\section{The Hypothesis}

$\mathbf{H}_{2}$ : There is a significant predictive relationship between strategic planning and SME performance measured by the subjective business performance measures.

\section{RELIABILITY AND VALIDITY}

Due to the multidimensionality of strategic planning and business performance constructs, the internal consistency reliability was established by calculating the Cronbach alpha coefficient. The overall coefficient alpha for the eight strategic planning factors was 0.93 , while the coefficient alpha for business performance factors was 0.89 . The coefficient alpha values for each of the eight factors of strategic planning were $0.91,0.86,0.84,0.71,0.64$, $0.69,0.73$, and 0.71 , respectively. The Cronbach reliability values for six strategic planning factors and business performance factors were above the acceptable benchmark of 0.70 (Bryman \& Bell, 2007), but the internal consistency reliability values for two factors - sources of information about the environment (0.64) and strategy implementation incentives (0.69) indicate marginal acceptance. A study of South African financial and business services' strategic planning practices by Murimbika (2011) also had two out of seventeen variables with Cronbach alpha values below 0.7. Similarly, in another developing country, a study of SMEs in the content of Iranian construction industry by Akhlagh, Moradi, Mehdizade, and Ahmed (2013) also had a variable with Cronbach alpha coefficient less that $0.70(0.69)$. The current results of the study could be attributed to the fact that this study was exploratory in nature in a developing country; i.e., more variables could be researched for inclusion in some of the dimensions.

Discriminant and construct validity were tested by conducting exploratory factor analysis. At each stage, scale purification was carried out to remove the items from the research instruments in order to improve the discriminant and construct validity. The removal of the items was done until all the items showed acceptable levels of discriminant validity (which means all the items only load on a common factor without cross loadings) and construct validity (which implies that all items relating to one dimension have factor loading of at least 0.40 ) (Dhurup, 2012). The results confirmed both discriminant and construct validity for both strategic planning and business performance scales. Through the computation of correlation analysis, the eight strategic planning factors showed convergence with the business performance, thus providing evidence of convergent validity. Predictive validity was tested by the regression models. The regression results indicate that the eight factors of strategic planning moderately correlated with business performance.

\section{RECOMMENDATIONS}

The results infer that increased practices of strategic planning lead to high levels of business performance. It is therefore important for SME owners and managers to understand the strategic planning factors in order to establish how to apply each factor to improve the performance of their businesses. A business should implement all eight dimensions of strategic planning as each dimension can assist to enhance the performance. In terms of the regression analysis, the results indicate that the formality of strategic planning process, strategy implementation incentives and strategy evaluation and control are the most influential dimensions to improve business performance. In this regard, SMEs should prioritise the implementation of these dimensions.

The positive relationship between strategic planning and SME performance should encourage SMEs to embrace the practice of strategic planning. By doing so, SMEs can enhance their performance, increase their chances to grow, and consequently strengthen their competitive advantage and prosper within the national economy.

There is need for businesses to scan the environment due to high levels of competition, uncertainty, and turbulence. This will assist them to gather information from the environment that is useful in strategic planning (Karami, 2008). Many owners/managers of South African SMEs seem to lack knowledge about the application of some environmental scanning techniques, as they indicated that they make use of only a few of them; namely, SWOT and PEST analyses. Most of the techniques, such as Porter's five competitive forces, value chain analysis, the gap analysis, and benchmarking, are rarely used by these SMEs. It is recommended that in order to address this knowledge gap, the government can assist by providing training on basic strategic planning education. This can be 
realised through funded or subsidised workshops, short courses, flexible university or college courses. This may help to improve the environmental scanning skills and knowledge of SME owners and managers.

In order to establish a common purpose, inspire, and motivate personnel in the business, (Forbes \& Seena, 2006), SMEs need to increase the usage of mission and vision statements. According to Mazzarol et al. (2009), SMEs need to recognise the importance of having a clear mission and vision statement, which is communicated to the employees. Being mission and vision driven will help them to have more focus on their long-term future and, hence, goal achievement.

Due to the increased complexity of their competitive environment, strategic planning in SMEs needs to be more formalised. Although not a panacea to business success, having a formalised and documented strategic plan will enable SMEs to communicate their intentions and to meet the requirements for government grant and bank loan applications. A formal strategic plan is also likely to require the owner/manager of the SME to review the business' vision, mission, and the external market conditions (Mazzarol et al., 2009). It is also recommended that policymakers and academics assist SME owners/managers through education programmes that train them to draft strategic plans. Rather than a short-term or medium-term perspective, it may be in the best interest of SMEs if they adopt a long time horizon when engaging in the strategic planning process, as this may assist them to have a longterm direction of the business (Dincer et al., 2006).

\section{LIMITATIONS}

Although the study provides fruitful insights regarding strategic planning and business performance within the SME industry, it is not without limitations. Data were gathered from only a limited number of respondents and SMEs in Gauteng province; hence, the results cannot be generalized to all SMEs in the country. Replication of this study is therefore warranted within the SME industry because this research has been exploratory in nature; future development of the robustness of the scale is required as this study is a valuable first step toward a better understanding of strategic planning dimensions. A possible direction for future research is to conduct a similar study in other provinces in South Africa or in other countries in order to examine similarities and differences. Future studies should also make a comparison amongst different types of industries. The reliance on the subjective views of SME owners/managers is a limitation in the study in terms of generalisation of the results to other SMEs because they could have different views about strategic planning and business performance.

\section{CONCLUSION}

This study examined the relationship between strategic planning and the performance of SMEs in Gauteng province, South Africa. The results indicate that the major strategic planning factors are mission and vision, environmental scanning, formality of strategic planning, strategy implementation incentives, sources of information about the environment, employee participation, evaluation and control, and time horizon of strategic planning. The study also confirmed that of these factors, formality of strategic planning, strategy implementation incentives and evaluation and control make significant contribution to strategic planning. Therefore, it is important for SMEs to prioritise these factors when they implement strategic planning in order to enhance their performance. This study can serve as a guide to SMEs owners and managers to properly implement strategic planning practices, which will enable the SME to play an increased role in the economy. Through strategic planning practices, South African SMEs may be cushioned from the dynamic, highly competitive and unstable business environment.

\section{AUTHOR INFORMATION}

Dr. Maxwell Sandada is a Lecturer in the Faculty of Management at Vaal University of Technology in South Africa. He holds a Doctor of Technology Degree in Business from Vaal University of Technology, South Africa. E-mail: maxwells@vut.ac.za (Corresponding author)

Dr. David Pooe is the Head of Logistics Department at Vaal University of Technology in South Africa. He has published several articles in refereed journals on various topics and currently supervises a number of Master's and Doctoral students. He holds a PhD in Business Management and two Master's Degrees in Business Management and Public and Development Management. E-mail: pooe@vut.ac.za 
Professor Manilall Dhurup is the Executive Dean of the Faculty of Management Sciences at Vaal University of Technology in South Africa. He has published over 60 accredited articles in referred journals and has presented papers at more than 30 international conferences all over the world. He has supervised more than 20 masters' and doctorate students and currently presents post-graduate induction and statistical programmes for masters' and doctoral students at the University. He holds a PhD in Marketing from the North-West University in South Africa. E-mail: royd@vut.ac.za

\section{REFERENCES}

1. Akhlagh, E. M., Moradi, M., Mehdizade, M., \& Ahmed, N. D. (2013). Strategies, performance diversity and development: An empirical analysis in Iran construction and housing industry. Iranian Journal of Management Studies, 6(2), 31-60.

2. Andersen, T. J. (2000). Strategic planning, autonomous actions and corporate performance. Long Range Planning, 33, 184-200.

3. Atkinson, H., \& Brown, J. B. (2001). Rethinking performance measures: assessing progress in UK hotels. International Journal of Contemporary Hospitality Management, 13(3), 128-135.

4. Bryman, A., \& Bell, E. (2007). Business research methods (2nd ed.). Oxford: University Press.

5. Chong, H. G. (2008). Measuring performance of small-and-medium sized enterprises: the grounded theory approach. Journal of Business and Public Affairs, 2(1), 1-10.

6. Chow, C. W., \& Van Der Stede, W. A. (2006).The use and usefulness of nonfinancial performance measures. Management Accounting Quarterly, 7(3), 1-8.

7. Dawes, J. (1999). The relationship between subjective and objective company performance measures in market orientation research: Further empirical evidence. Marketing Bulletin, 10(3), 65-75.

8. Desai, A. B. (2000). Does strategic planning create value? The stock market's belief. Management Decision Journal, 38(10), 685-693.

9. Dhurup. M. (2012). Determinants of internal service quality and the relationship with internal customer satisfaction. African Journal of Business Management, 6(11), 4185-4195.

10. Dincer, O., Tatoglu, E., \& Glaister, K. W. (2006). The strategic planning process: Evidence from Turkish firms. Management Research News, 29(4), 206-219.

11. Efendioglu, A. M., \& Karabulut, A. T. (2010). Impact of strategic planning on financial performance of companies in Turkey. International Journal of Business and Management, 5(4), 3-12.

12. Ehlers, T., \& Lazenby, K. (2006). Strategic management: Southern African concepts and cases. Pretoria: Van Schaik Publishers.

13. Falshaw, J. R., Glaister, K. W., \& Tatoglu, E. (2006). Evidence on formal strategic planning and company performance. Management Decision Journal, 44(1), 9-30.

14. Forbes, D. J., \& Seena, S. (2006). The value of a mission statement in an association of not-for-profit hospitals. International Journal of Health Care Quality Assurance, 19(5), 400-419.

15. Fraser, D. L., \& Stupak, R. J. (2002). A synthesis of the strategic planning process with the principles of learning, leading and linking. International Journal of Public Administration, 25(9), 1199-1220.

16. French, J. S., Kelly, S., \& Harrison, J. (2004).The role of strategic planning in the performance of small professional services firms. Journal of Management Development, 23(8), 765-776.

17. Gadiesh, O., \& Gilbert, J. L. (2001).Transforming corner office strategy into frontline action. Harvard Business Review, 16-25. May.

18. Goncalves, H. S. (2009). Proposal of a strategy model planning aligned to the balanced scorecard and the quality environments. The TQM Journal, 21(5), 462-472.

19. Hair, J. F., Anderson, R. E., Tatham, R. L., \& Black, W. C. (1998). Multivariate data analysis: With readings. EngleWood Cliff, NJ: Prentice-Hall.

20. Huang, C. J. (2006). Strategic planning and dysfunction: The dark side of mandating a formal planning system. Soochow Journal of Political Science, 22, 47-71.

21. Johnson, R. B., \& Onwuegbuzie, A. J. (2004). Mixed methods research: A paradigm whose time has come. American Educational Research Association, 33(7), 14-26.

22. Jusoh, R., \& Parnell, J. A. (2008). Competitive strategy and performance measurement in the Malaysian context. Management Decision, 46(1), 5-31. 
23. Kantabutra, S. (2008). Vision effects in Thai retail stores: practical implications. International Journal of Retail and Distribution Management, 36(4), 323-342.

24. Karami, A. (2008). An investigation on environmental scanning and growth strategy in high tech small and medium sized enterprises. Paper read at the high technology firms conference held at the University of Twente between 21 and 23 May 2008. Twente, 1-17.

25. Kivela, J., Inbakaran, R., \& Reece, J. (1999). Consumer research in the restaurant environment, part 1: A conceptual model of dining satisfaction and return patronage. International Journal of Contemporary Hospitality Management, 11(5), 205-222.

26. Kraus, S., Harms, R., \& Schwarz, E. J. (2006). Strategic planning in smaller enterprises - new empirical findings. Management Research News, 29(6), 334-344.

27. Laljit, C. R. (2006). The business strategy development among SMEs in the Kwa-Zulu Natal clothing manufacturing sector. (Master of Business Administration dissertation). Durban University of Technology. Durban.

28. Mazzarol, T., Rebound, S., \& Soutar, G. N. (2009). Strategic planning in growth oriented small firms. International Journal of Entrepreneurial Behavior and Research, 15(4), 320-345.

29. Mcllquham-Schmidt, A. (2010). Strategic planning and corporate performance. What is the relationship? (working paper 02). Aarhus University Business School.

30. Mintzberg, H. (1994). The rise and fall of strategic planning. New York: The Free Press.

31. Mohutsiwa, M. (2012). Strategic entrepreneurship and performance of SMEs in South Africa. (Master of Management Dissertation). University of Witwatersrand. Johannesburg.

32. Murimbika, M. (2011). Influence of strategic management practices on the entrepreneurial orientation of South African firms in the financial and business services sectors. (Masters Dissertation). University of Witwatersrand. Johannesburg.

33. Naidoo, K. K. (2006). The strategic processes of small businesses operating in a turbulent environment: A retail community pharmacy perspective. (Doctor of Business Leadership Dissertation). University of South Africa. Pretoria.

34. Nkulu, M. (2012). The use of strategic planning for small, medium and micro enterprises in the retail industry. (Master of Commerce Dissertation). University of Johannesburg. Johannesburg.

35. Odame, A. M. (2007). The relevance of strategic planning for entrepreneurial businesses in South Africa. (Master of Business Administration dissertation). University of Pretoria.

36. Okumus, F. (2003). A framework to implement strategies in organizations. Management Decision Journal, 4l(9), 871-882.

37. O'regan, N., \& Ghobadian, A. (2004).The importance of capabilities for strategic direction and performance. Management Decision, 42(2), 292-312.

38. Panigyrakis, G. G., \& Theodoridis, P. K. (2009). Internal marketing impact on business performance in a retail context. International Journal of Retail and Distribution Management, 37(7), 600-628.

39. Phillips, P., Davies, F., \& Moutinho, L. (1999). The interactive effects of strategic planning on hotel performance: a neural network analysis. Management Decision Journal, 37(3), 279-288.

40. Phillips, P. (2000). The strategic planning/finance interface: Does sophistication really matter? Management Decision, 38(8), 541-549.

41. Popoola, S. O. (2000). Scanning the environment for competitive advantage: A study of corporate banking managers in Nigeria. Libri, 50, 210-216.

42. Punn, K. F., \& White, A. S. (2005). A performance measurement paradigm for integrating strategy formulation: A review of systems and frameworks. International Journal of Management Reviews, 7(1), 49-71.

43. Saffu, K., \& Manu, T. (2003). Strategic capabilities of Ghanaian female business owners and the performance of their ventures. Unfiled notes, Brock University, 1-17.

44. Sedmark, M., \& Longhurst, P. (2010). Methodological choices in enterprise systems research. Business Process Management Journal, 16(1), 76-92.

45. Schiffman, L. N., \& Kanuk, L. L. (2009). Consumer Behaviour (9th ed.). London: Pearson.

46. Schraeder, M. (2002). A simplified approach to strategic planning. Practical considerations and illustrated example. Business Process Management Journal, 8(1), 8-18.

47. Speculand, R. (2009). Six necessary mind shifts for implementing strategy. Business Strategy Series, 10(3), 167-172. 
48. Sum, C., Jukow, L., \& Chen, S. (2004).Taxonomy of operations strategies of high performing small and medium enterprises in Singapore. International Journal of Operations and Production Management, 24(3), 321-345.

49. Tang, T., \& Zhang, Y. (2005). Marketing strategy and business performance of small construction firms in China. Macquarie Graduate School of Management working papers in management: 1-12. March.

50. Tapinos, E., Dyson, R. G., \& Meadows, M. (2005).The impact of performance measurement in strategic planning. International Journal of Productivity and Performance, 54(5/6), 370-384.

51. Verbeen, F. H. M., \& Boons, A. N. A. M. (2009). Strategic priorities, performance measures and performance: An empirical analysis in Dutch firms. European Management Journal, 27, 113-128.

52. Welman, K. C., Kruger, S. J. P., \& Mitchell, B. (2005). Research methodology (3rd ed.). Cape Town: Oxford University Press.

53. Zikmund, Babin, Car, \& Griffin, (2009). Business research methods (8th ed.). Chicago: South Western Education. 
NOTES 